Review

\title{
The Controversial History of Hormone Replacement Therapy
}

\author{
Angelo Cagnacci * and Martina Venier \\ Obstetrics and Gynecology Unit, Azienda Sanitaria Universitaria Integrata di, 33100 Udine, Italy; \\ martina04venier@gmail.com \\ * Correspondence: angelo.cagnacci@uniud.it; Tel.: +39-0432-559635; Fax: +39-0432-559641
}

Received: 8 July 2019; Accepted: 13 September 2019; Published: 18 September 2019

\begin{abstract}
The history of hormone replacement therapy (HRT) started in the 1960s, with very high popularity in the 1990s. The first clinical trials on HRT and chronic postmenopausal conditions were started in the USA in the late 1990s. After the announcement of the first results of the Women's Health Initiative (WHI) in 2002, which showed that HRT had more detrimental than beneficial effects, HRT use dropped. The negative results of the study received wide publicity, creating panic among some users and new guidance for doctors on prescribing HRT. The clear message from the media was that HRT had more risks than benefits for all women. In the following years, a reanalysis of the WHI trial was performed, and new studies showed that the use of HRT in younger women or in early postmenopausal women had a beneficial effect on the cardiovascular system, reducing coronary disease and all-cause mortality. Notwithstanding this, the public opinion on HRT has not changed yet, leading to important negative consequences for women's health and quality of life.
\end{abstract}

Keywords: hormone replacement therapy; osteoporosis; breast cancer; cardiovascular disease

\section{From the Past to the Present}

In the 20th century, the interest in menopausal disorder has been increasing, but it took a long time to realize the real impact of hormone depletion on women's health. The clinical conditions associated with menopause were identified as "Hormone Deficiency Syndrome" [1], which included, besides hot flashes, other late onset chronic diseases such as osteoporosis, cardiovascular events, Alzheimer's disease, and vaginal atrophy. At the beginning of the 20th century, the Food and Drug Administration (FDA )approved an estrogen product for the first time, Preamirin ${ }^{\circledR}$, for the treatment of hot flashes [2].

The feminist movement in the 1960s changed women's status and life expectancy, encouraging menopausal therapy, especially in European countries, with the concept of "feminine forever". Wilson's book, published in 1966 ("feminine forever"), became a bestseller, with its claim that "menopause is a hormone deficiency disease, curable and totally preventable, just take estrogen" [3]. Hormone replacement therapy (HRT) was presented as a therapy that could allow women to free themselves from the malediction of estrogen loss and conserve their femininity. In the 1970s, the finding that unopposed estrogen supplements were associated with an increased risk of endometrial cancer had a bad impact on HRT's reputation [4,5]. Ziel et al. observed a probable connection between the administration of conjugated estrogen alone and the development of endometrial cancer [4].

Nevertheless, in the following years, researchers discovered that reducing the dosage of estrogen and combining it with progesterone could reduce the risk of endometrial cancer [6]. Such combined therapy was recommended for women with an intact uterus, raising renewed enthusiasm for HRT treatment. 
The FDA initially approved HRT only for the treatment of hot flashes and not for the prevention of chronic conditions, but in 1988 the prevention of osteoporosis was included among the FDA-approved indications $[7,8]$.

Furthermore, in the same years, numerous observational studies [9-12] suggested that HRT had various benefits, not only with regard to the treatment of menopausal symptoms, but also in the prevention of chronic diseases. Thus, the idea switched from "feminine forever" to "healthy forever". The use of HRT increased further, and the American College of Physicians developed the first guidelines for using HRT as a preventative therapy for the chronic diseases of postmenopausal women $[13,14]$, even if experts raised some concern about the impact that progestin may have on estrogen benefits, particularly in the cardiovascular system [15].

On the basis of the claimed positive effect of HRT on cardiovascular health, the FDA required that this supposed HRT-induced cardiovascular benefit be confirmed by randomized clinical trials.

The first randomized clinical trial was a study of secondary prevention of cardiovascular disease, the Heart and Estrogen/Progestin Replacement Study (HERS) [16]. This study enrolled 2736 postmenopausal women with established coronary heart disease. Enrolled women were randomized to receive HRT ( $0.625 \mathrm{mg}$ of conjugated equine estrogens and $2.5 \mathrm{mg}$ of medroxyprogesterone acetate) or a placebo. No difference was found between the two groups after four years of follow-up, but in the HRT group, an increase of coronary events (nonfatal myocardial infarction or coronary heart disease (CHD) death) was found after one year. This induced increase declined in the subsequent years [16].

In 1998, the Women's Health Initiative (WHI) was started, which was the largest randomized study to date that was aimed at evaluating the effect of HRT on the most common causes of death and disability in postmenopausal women, such as cardiovascular disease, cancer, and osteoporosis. Women with uteri $(16,608$ participants) were randomized and received a combination of $0.625 \mathrm{mg}$ Conjugated Equine Estrogens (CEE) and $2.5 \mathrm{mg}$ of medroxyprogesterone acetate, and women without uteri (10,739 participants) were randomized and received $0.625 \mathrm{mg}$ of conjugated equine estrogen or a placebo. The first results of the WHI were published in 2002 after a mean follow-up period of 5.2 years. In the group with intact uteri, an increased incidence of coronary heart disease and breast cancer was observed in concomitance with a reduction of osteoporotic fractures and colorectal cancer [17]. Given these results, it seemed that the risks outweighed the benefits, and the trial was prematurely discontinued. The data were largely disseminated to the media, creating panic among HRT users and forcing new guidance for doctors on prescribing HRT. The message was that HRT, with no specification of type and route of administration, was associated with more risks than benefits. However, no distinction was made between users and their age.

The trial with only estrogen (performed in hysterectomized women) continued, and the preliminary data were published in 2004 [18]. In addition, this trial was stopped prematurely after 6.8 years of follow-up due to evidence of a small increased risk of ischemic stroke in the absence of other significant cardiovascular benefits [18]. In spite of the benefits (such as a reduction of osteoporotic fracture and colon cancer) and of the not-increased risk of breast cancer or cardiovascular disease, the overall message on HRT remained negative. After these announcements, the UK regulatory authorities issued an urgent safety restriction about HRT, recommending that doctors should prescribe the lowest effective dose for symptom relief, should use it only as a second-line treatment for the prevention of osteoporosis, and should not use it in asymptomatic postmenopausal women.

Since that time, there have been ongoing discussions and controversies about the WHI design and conclusions, and many of its results have been extensively debated. It emerged that one important limitation of the WHI was that most of the participants were more than a decade past their final menstrual period, raising the question of whether the results of the trial could be applied to younger women. Furthermore, the WHI tested only CEE either alone or in combination with a single progestin, medroxyprogesterone acetate. As a result, the WHI findings did not answer doubts about the safety and effectiveness of other HRT formulations, regimens, and delivery methods. Despite its limitations, 
the WHI had a negative impact on the global perception of HRT, leading to a marked decline in HRT utilization. Many doctors stopped prescribing HRT, and many women abandoned HRT immediately.

It has been suggested that the conflicting findings between the WHI and previous observational studies were the consequence of the different ages of the enrolled women. Some observational studies had included symptomatic women who had started HRT near the onset of menopause, while women enrolled in the WHI trial were asymptomatic, older (average age 63.2), and frequently more than 10 years on from the start of menopause. It has been suggested that a "window of opportunity" may exist, a period of time close to menopause where the benefits of HRT exceed the risks [19].

The follow-up of the WHI continued for 13 years, and some results, including an age stratification of the cardiovascular outcomes, were published in the following years [20-23]. A reanalysis of the WHI trial with new studies and a metanalysis showed that the use of HRT in younger women (50-59 years) or in early postmenopausal women (within 10 years of menopausal onset) had a beneficial effect on the cardiovascular system, reducing coronary diseases and all-cause mortality [22,24-27]. Furthermore, a large controlled trial from Denmark (reported in 2012) demonstrated that healthy women taking combined HRT for 10 years immediately after menopause had a reduced risk of heart disease and death from heart disease [28]. Unfortunately, these data did not receive appropriate coverage by the media, and the fear regarding HRT has persisted.

Thus, the story of HRT over the years has shown a trend with two peaks of utilization: a first rise in the 1960s and a second, higher increase in the years 1999-2000, before the publication of the WHI data. After these years, there was a precipitous decline in HRT use in many countries [29]. For instance, the use of HRT dramatically declined by $46 \%$ in the USA [30] and by $28 \%$ in Canada [31], and similar data were observed in European countries such as Germany [32,33] or the United Kingdom [34].

If HRT was really harmful to the health of postmenopausal women, its massive reduction in use should have resulted in an improvement in women's health. Observational studies have tried to show trends of hormone-related cancers and chronic conditions following the WHI publications. Cancer and chronic conditions are multifactorial, and modification of a single factor, such as HRT use, may not result in a clear epidemiological change. Still, the analysis of epidemiological trends or modifications in the post-WHI era may give additional insights into the role played by HRT in women's health (Table 1).

Table 1. Epidemiological modification in the incidence of hormone-related cancers, cardiovascular disease (CVD), and bone fractures in the post-Women's Health Initiative (WHI) era.

\begin{tabular}{cc}
\hline Disease & Modification \\
\hline Breast Cancer & Decreased or Unchanged \\
\hline Endometrial Cancer & Increased \\
\hline CVD & Increased or Unchanged \\
\hline Bone Fractures & Increased or Unchanged \\
\hline
\end{tabular}

In bold is the stronger evidence.

\section{Breast Cancer}

\subsection{Effect of HRT}

Over the years, data regarding the impact of HRT on breast safety and breast cancer mortality have been controversial. Most of the meta-analyses and observational studies performed in the 1990s reported no increase in the risk of breast cancer with estrogen use [35]. However, some increased risks related to dose and duration of use were found with the administration of combined estrogen-progesterone therapies [36].

The WHI reported an increased risk of breast cancer in the women treated with a combination of conjugated estrogen and medroxyprogesterone acetate [17], a risk that was significantly higher than in placebo users after 5.6 years of treatment (approximately $6-7$ years) $[37,38]$. Vice versa, the risk of breast 
cancer was significantly lower than in placebo users for those women treated with only conjugated estrogen [37,39]. One important, but incorrect, thought reported by the media after the WHI trial publication was that HRT causes breast cancer "de novo". However, this study did not distinguish between de novo tumor development and the growth of an occult tumor present before the beginning of therapy. After analyses of the biology of occult tumors, current opinion about breast safety with HRT has changed. The modern thinking is that estrogen could have a promotional and noncarcinogenic effect on occult tumor cells and that this effect is probably greater with an estrogen-progesterone therapy [40].

\subsection{Consequence of HRT Withdrawal}

Following the publication of the WHI results and the associated drop of HRT use, some envisioned a concomitant decline of breast cancer incidence. However, the impact of HRT cessation showed an important variability between nations. Clarke and colleagues were the first to publish data about the incidence of breast cancer between 2001 and 2003 [41]. The authors reported that after the WHI publication, the use of HRT in northern California declined by $68 \%$, and at the same time, breast cancer incidence declined by 10\%. A study performed in California between 2001 and 2004 [42] similarly hypothesized that a decline in breast cancer incidence was linked to reduced HRT use. These data were in accordance with those observed in the Surveillance, Epidemiology, and End Results (SEER) study, which showed a 6.7\% decrease in breast cancer incidence in 2003 [29]. Other western countries documented a reduction in breast cancer incidence after the reduced use of HRT [43]. In Germany, breast cancer incidence declined by $8.8 \%$ annually from 2002 to 2005, with an almost 50\% reduction in HRT use [44]. In France, the breast cancer rate decreased by 14.7\% from 2003 to 2007, with a reduction in HRT use from 32\% to 11\% between the years 2001 and 2007 [45]. In Australia, a 6.7\% decline in breast cancer incidence was observed in 2003, with a simultaneous $8 \%$ reduction in HRT use between 2001 and 2003 [46]. In Canada, an 8\% decreased incidence in breast cancer was observed every year from 2002 to 2004, with a 15\% reduction in HRT use [47].

In Italy, the Netherlands, and Spain, the absolute decline of therapy after 2002 did not translate into a decline in breast cancer rates [43]. In addition, in the UK, the use of HRT showed a peak of $25 \%$ in 2000 and decreased thereafter. In spite of that, breast cancer incidence declined $0.8 \%$ per year from 1999 to 2006 [48]. Interestingly, the incidence of estrogen receptor-positive breast cancer in the USA increased to a maximum in 1999, with a downward trend starting in 2000, at least two years prior to the WHI publications [43,49]. Moreover, after some years, there was a new rise in breast cancer incidence (for both lobular and ductal breast cancer), such that by 2012, the rates were like those of 2001. This could mean that other factors besides HRT can explain the trend in breast cancer. Likely, some of these data can be explained by changes in the national screening programs for breast cancer. High rates of mammography, which has been extended to younger women, may have resulted in a greater incidence of breast cancer in the years following screening implementation, followed by a decline of breast cancer incidence as a consequence of the early diagnoses of the previous years [50,51].

\section{Endometrial Cancer}

\subsection{Effect of HRT}

The use of unopposed estrogen has been associated with an increased risk of endometrial cancer [4]. Consequently, guidelines have indicated that in women with uteri, estrogen therapy should be prescribed together with a progestin molecule [8]. Evidence of reduced endometrial cancer risk with combined HRT was well represented in the HERS trial, which showed seven fewer endometrial cancer cases per 10,000 in women using HRT than in placebo users [52]. Similarly, the Million Women Study reported that combined HRT therapy reduced the risk of endometrial cancer [53]. Continuous combined therapy has better endometrial safety than sequential therapy does [54,55]. A large Finnish case-control study [56] showed that sequential therapy induced an elevated risk of endometrial cancer when used 
for longer than 10 years. However, the roles of different types of progestagen remain to be assessed. In two observational studies, the most commonly used progestin molecules, norethisterone acetate and medroxyprogesterone acetate, did not differ in their protection from endometrial cancer $[53,56]$. On the basis of the literature, oral micronized progesterone administered sequentially for 12-14 days/month at a dose of $200 \mathrm{mg} /$ day is effective for endometrial protection for up to five years of use [57]. However, for treatments longer than five years in the E3N cohort study [58], combined therapy with oral micronized progesterone or dydrogesterone was associated with an increased risk of endometrial cancer [59].

\subsection{Consequences of HRT Withdrawal}

After the WHI publication and the drop in HRT prescription, endometrial carcinoma rates increased between 2001 and 2012 [60]. Similarly, in England, Martin and colleagues observed a change in endometrial cancer mortality after 2002, with nine additional endometrial cancer deaths per year [51].

\section{Cardiovascular Disease}

\subsection{Effect of HRT}

The incidence of cardiovascular events increases in postmenopausal women, particularly in those experiencing severe vasomotor symptoms. The Study of Women's Health Across the Nation (SWAN) showed that women with hot flashes had higher subclinical CVD, including greater aortic calcification, poorer endothelial function, and higher intima media thickness, than did women without menopausal symptoms [61-63]. Clinical studies have shown that HRT favorably impacts the risk factors for CVD [64-69]. The clinical efficacy could be related to early treatment, but also could be related to the administration of HRT to those with a higher cardiovascular risk due to their symptoms. This was not the case in the WHI, where HRT was given years after menopause and to asymptomatic women. Thus, it is not surprising that the results of the WHI trial did not confirm a protective effect of HRT against coronary heart disease, stroke, and venous thromboembolism [17]. However, a reanalysis of the data using age stratification reported that in women within 10 years of the onset of menopause, the administration of HRT decreased the rate of coronary artery disease and all-cause mortality [22]. Two subsequent meta-analyses, which used cumulated data from 23 and 30 randomized clinical trials, respectively, reported a decrease in CVD and all-cause mortality in HRT users younger than 60 years of age or in those who began menopause less than 10 years prior [24,25]. More recent randomized trials have tested the timing hypothesis, the Early versus Late Intervention with Estradiol (ELITE) study [70] and the Kronos Early Estrogen Prevention Study (KEEPS) [71], and have reported a protective effect of HRT in young women close to menopause. More recently, the Danish Osteoporosis Prevention Study (DOPS) reported the same findings after 10 years of treatment with HRT versus a placebo [28].

\subsection{Consequences of HRT Withdrawal}

From the above data, it could be expected that a lack of treatment of symptomatic postmenopausal women may have translated into an increase in cardiovascular events after 2002. A Finnish study reported increased deaths from myocardial infarctions and strokes in women discontinuing HRT, especially in those younger than 60 years of age [72]. In the USA, a report comparing male and female mortality between two periods, the mid-1990s and between 2002 and 2006 [73], reported a reduction in male mortality but an increase in female mortality in the same timeframe. An English ecological study reported unfavorable changes in myocardial infarctions and strokes subsequent to the HRT fall following the WHI publication [51]. In contrast, one ecological study performed in the USA after 2002 reported a correlation between the fall in HRT use and a reduced incidence of acute myocardial infarction [74]. 


\section{Fractures}

\subsection{Effect of HRT}

Postmenopausal osteoporosis is a consequence of estrogen withdrawal in which inflammation plays a multifactorial role [75,76]. Clinical studies have unanimously shown that any kind of HRT is capable of reducing bone turnover, reducing bone reabsorption, and increasing bone mineral density. Both high bone turnover and low bone mineral density are risk factors for bone fractures. The supposed preventive effect of HRT on bone fractures has been reported by many observational studies [77,78]. The WHI was the first randomized trial that showed the clear efficacy of HRT in reducing vertebral and hip fractures by about 34\% [17]. The same data were obtained in the DOPS study [79]. The effect was demonstrated in a population of normal women that was not specifically suffering from osteoporosis, i.e., a clinical situation where other antiosteoporotic therapies failed to show a preventive effect.

\subsection{Consequences of HRT Withdrawal}

The follow-up to the WHI study showed no increase in fractures five years after HRT withdrawal [80]. In another observational study (after 15 years of follow-up), conserved beneficial effects on bone were reported in women who used HRT for more than five years [81]. However, in a large study, Islam and colleagues found that the risk of fractures in postmenopausal women increased in the three years following the publication of the WHI [82]. An Italian analysis estimated 43,000 extra bone fractures per year in the USA that were associated with decreased HRT use [83]. A more recent longitudinal observational study concluded that women who discontinued HRT had a higher risk of fractures compared to those who continued therapy, which has an important effect on women's health [84].

\section{Conclusions}

The controversial history of HRT is about the history of a powerful pathogenetic therapy for all postmenopausal disturbances. Its effects on symptoms are and were immediately visible, at first prompting rapidly growing estrogen use. A lack of knowledge about its side effects and complications, particularly in the endometrium, prompted consequences that limited HRT use. Subsequent association with progestin allowed for the widespread use of HRT, with favorable consequences on many aspects of women's health. Unfortunately, the surge in HRT use and its consolidation was abruptly stopped by the publication of the WHI trial, which was inadequately designed, evaluated, and reported. The damage done was huge, basically leaving many symptomatic women without an effective treatment, even if the epidemiological data were not strong enough to document a clear harm to women's health. Although most of the evidence obtained was only with oral conjugated estrogen with or without medroxyprogesterone acetate, further studies and analyses have consolidated the view that HRT is highly beneficial when given to symptomatic women within 10 years since the onset of menopause or to symptomatic women that are under 60 years of age. However, the damage remains, and low HRT use, which is unjustified, continues to occur throughout the world.

Author Contributions: Both authors contributed to reviewing the literature, writing the paper, and critically revise the paper.

Funding: This research received no external funding.

Conflicts of Interest: None of the authors report any conflict of interest with the data and concepts expressed in the present manuscript. No author has a conflict of interest that is relevant to the subject matter or materials included in this work. 


\section{References}

1. Keep, P.A.; Kellerhals, J. The ageing woman. In Ageing and Estrogens. Frontiers of Hormone Research, Proceedings of the 1st International Workshop on Estrogen Therapy, Geneva, Switzerland, 1972; Lauritzen, C., van Keep, P.A., Eds.; S. Karger: Basel, Switzerland, 1973; Volume 2, pp. 160-173. [CrossRef]

2. Kling, J. The Strange Case of Premarin Modern Drug Discovery. 2000. Available online: http://pubs.acs.org/ subscribe/archive/mdd/v03/i08/html/kling.html (accessed on 22 July 2019).

3. Wilson, R.A. In Feminine Forever; Evans, M., Ed.; Lippincott \& Co.: Philadelphia, PA, USA, 1996.

4. Ziel, H.K.; Finkle, W.D. Increased risk on endometrial carcinoma among users of conjugated estrogens. N. Engl. J. Med. 1975, 293, 1167-1170. [CrossRef] [PubMed]

5. Smith, D.C.; Prentice, R.; Thomson, D.J.; Herrmann, W.L. Association of exogenous estrogen and endogenous carcinoma. N. Engl. J. Med. 1975, 293, 1164-1167. [CrossRef] [PubMed]

6. Woodruff, J.D.; Pickar, J.H. Incidence of endometrial hyperplasia in postmenopausal women taking conjugated estrogens (Premarin) with medroxyprogesterone acetate or conjugated estrogens alone. The Menopause Study Group. Am. J. Obstet. Gynecol. 1994, 170, 1213-1223. [CrossRef]

7. Lobo, R.A. Hormone-replacement therapy: Current thinking. Nat. Rev. Endocrinol. 2017, 13, $220-231$. [CrossRef] [PubMed]

8. North American Menopause Society. The 2012 hormone therapy position statement of the North American Menopause Society. Menopause 2012, 19, 257-271. [CrossRef]

9. Grodstein, F.; Stampfer, M.J.; Colditz, G.A.; Willett, W.C.; Manson, J.E.; Joffe, M.; Rosner, B.; Fuchs, C.; Hankinson, S.E.; Hunter, D.J.; et al. Postmenopausal hormone therapy and mortality. N. Engl. J. Med. 1997, 336, 1769-1775. [CrossRef]

10. Yaffe, K.; Sawaya, G.; Lieberburg, I.; Grady, D. Estrogen therapy in postmenopausal women: Effects on cognitive function and dementia. JAMA 1998, 279, 688-695. [CrossRef]

11. Stampfer, M.J.; Colditz, G.A. Estrogen replacement therapy and coronary heart disease: A quantitative assessment of the epidemiologic evidence. Prev. Med. 1991, 20, 47-63. [CrossRef]

12. Grady, D.; Rubin, S.M.; Petitti, D.B.; Fox, C.S.; Black, D.; Ettinger, B.; Ernster, V.L.; Cummings, S.R. Hormone therapy to prevent disease and prolong life in postmenopausal women. Ann. Intern. Med. 1992, 117, 1016-1037. [CrossRef]

13. Lobo, R.A.; Pickar, J.H.; Stevenson, J.C.; Mack, W.J.; Hodis, H.N. Back to the future: Hormone replacement therapy as part of a prevention strategy for women at the onset of menopause. Atherosclerosis 2016, 254, 296-304. [CrossRef]

14. American Medical Association. Guidelines for counseling postmenopausal women about preventive hormone therapy. American College of Physicians. Ann. Intern. Med. 1992, 117, 1038-1041. [CrossRef] [PubMed]

15. Lobo, R.A.; Whitehead, M. Too much of a good thing? Use of progestogens in the menopause: An international consensus statement. Fertil. Steril. 1989, 51, 229-231. [CrossRef]

16. Hulley, S.; Grady, D.; Bush, T.; Furberg, C.; Herrington, D.; Riggs, B.; Vittinghoff, E. Randomized trial of estrogen plus progestin for secondary prevention of coronary heart disease in postmenopausal women. Heart and Estrogen/progestin Replacement Study (HERS) Research Group. JAMA 1998, 280, 605-613. [CrossRef] [PubMed]

17. Rossouw, J.E.; Anderson, G.L.; Prentice, R.L.; LaCroix, A.Z.; Kooperberg, C.; Stefanick, M.L.; Jackson, R.D.; Beresford, S.A.; Howard, B.V.; Johnson, K.C.; et al. Writing Group for the Women's Health Initiative Investigators. Risks and benefits of estrogen plus progestin in healthy postmenopausal women: Principal results from the Women's Health Initiative randomized controlled trial. JAMA 2002, 288, 321-333. [CrossRef] [PubMed]

18. Anderson, G.L.; Limacher, M.; Assaf, A.R.; Bassford, T.; Beresford, S.A.; Black, H.; Bonds, D.; Brunner, R.; Brzyski, R.; Caan, B.; et al. Effects of conjugated equine estrogen in postmenopausal women with hysterectomy: The Women's Health Initiative randomized controlled trial. JAMA 2004, 291, 1701-1712. [CrossRef]

19. Hodis, H.N.; Wendy, J.M. A window of opportunity: The reduction of coronary heart disease and total mortality with menopausal therapies is age and time dependent. Brain Res. 2011, 1379, 244-252. [CrossRef]

20. Stuenkel, C.A.; Gass, M.L.; Manson, J.E.; Lobo, R.A.; Pal, L.; Rebar, R.W.; Hall, J.E. A decade after the Women's Health Initiative-The experts do agree. Menopause 2012, 19, 846-847. [CrossRef] 
21. Stevenson, J.C.; Hodis, H.N.; Pickar, J.H.; Lobo, R.A. Coronary heart disease and menopause management: The swinging pendulum of HRT. Atherosclerosis 2009, 207, 336-340. [CrossRef]

22. Manson, J.E.; Chlebowski, R.T.; Stefanick, M.L.; Aragaki, A.K.; Rossouw, J.E.; Prentice, R.L.; Anderson, G.; Howard, B.V.; Thomson, C.A.; LaCroix, A.Z.; et al. Menopausal hormone therapy and health outcomes during the intervention and extended poststopping phases of the Women's Health Initiative randomized trials. JAMA 2013, 310, 1353-1368. [CrossRef]

23. Hsia, J.; Langer, R.D.; Manson, J.E.; Kuller, L.; Johnson, K.C.; Hendrix, S.L.; Pettinger, M.; Heckbert, S.R.; Greep, N.; Crawford, S.; et al. Women's Health Initiative Investigators. Conjugated equine estrogens and coronary heart disease: The Women's Health Initiative. Arch. Intern. Med. 2006, 166, 357-365. [CrossRef]

24. Salpeter, S.R.; Walsh, J.M.; Greyber, E.; Salpeter, E.E. Brief report: Coronary heart disease events associated with hormone therapy in younger and older women. A meta-analysis. J. Gen. Intern. Med. 2006, 21, 363-366. [CrossRef] [PubMed]

25. Salpeter, S.R.; Walsh, J.M.; Greyber, E.; Ormiston, T.M.; Salpeter, E.E. Mortality associated with hormone replacement therapy in younger and older women: A meta-analysis. J. Gen. Intern. Med. 2004, 19, 791-804. [CrossRef] [PubMed]

26. Boardman, H.M.; Hartley, L.; Eisinga, A.; Main, C.; i Figuls, M.R.; Cosp, X.B.; Sanchez, R.G.; Knight, B. Hormone therapy for preventing cardiovascular disease in postmenopausal women. Cochrane Database Syst. Rev. 2015. [CrossRef] [PubMed]

27. Rossouw, J.E.; Prentice, R.L.; Manson, J.E.; Wu, L.; Barad, D.; Barnabei, V.M.; Ko, M.; LaCroix, A.Z.; Margolis, K.L.; Stefanick, M.L. Postmenopausal hormone therapy and cardiovascular disease by age and years since menopause. JAMA 2007, 297, 1465-1477. [CrossRef] [PubMed]

28. Schierbeck, L.L.; Rejnmark, L.; Tofteng, C.L.; Stilgren, L.; Eiken, P.; Mosekilde, L.; Køber, L.; Beck Jensen, J.E. Effect of hormone replacement therapy on cardiovascular events in recently postmenopausal women: Randomized trial. BMJ 2012, 345, e6409. [CrossRef] [PubMed]

29. Ravdin, P.M.; Cronin, K.A.; Howlader, N.; Berg, C.D.; Chlebowski, R.T.; Feuer, E.J.; Edwards, B.K.; Berry, D.A. The decrease in breast-cancer incidence in 2003 in the United States. N. Engl. J. Med. 2007, 356, 1670-1674. [CrossRef] [PubMed]

30. Buist, D.S.; Newton, K.M.; Miglioretti, D.L.; Beverly, K.; Connelly, M.T.; Andrade, S.; Hartsfield, C.L.; Wei, F.; Chan, K.A.; Kessler, L. Hormone therapy prescribing patterns in the United States. Obstet. Gynecol. 2004, 104, 1042-1050. [CrossRef] [PubMed]

31. Guay, M.P.; Dragomir, A.; Pilon, D.; Moride, Y.; Perreault, S. Changes in pattern use, clinical characteristics and persistence rate of hormone replacement therapy among postmenopausal women after the WHI publication. Pharmacoepidemiol. Drug Saf. 2007, 16, 17-27. [CrossRef]

32. Heitmann, C.; Greiser, E.; Dören, M. The impact of the Women's Health Initiative randomized controlled trial 2002 on perceived risk communication and use of postmenopausal hormone therapy in Germany. Menopause 2005, 12, 405-411. [CrossRef]

33. Clanget, C.; Hinke, V.; Lange, S.; Fricke, R.; Botko, R.; Pfeilschifter, J. Patterns of hormone replacement therapy in a population-based cohort of postmenopausal German women. Changes after HERS II and WHI. Exp. Clin. Endocrinol. Diabetes 2005, 113, 529-533. [CrossRef]

34. Menon, U.; Burnell, M.; Sharma, A.; Gentry-Maharaj, A.; Fraser, L.; Ryan, A.; Parmar, M.; Hunter, M.; Jacobs, I.; UKCTOCS Group. Decline in use of hormone therapy among postmenopausal women in the United Kingdom. Menopause 2007, 14, 462-467. [CrossRef] [PubMed]

35. Nelson, H.D.; Humphrey, L.L.; Nygren, P.; Teutsch, S.M.; Allan, J.D. Postmenopausal Hormone Replacement Therapy: Scientific Review. JAMA 2002, 288, 872-881. [CrossRef] [PubMed]

36. Collaborative Group on Hormonal Factors in Breast Cancer. Breast cancer and hormone replacement therapy: Collaborative reanalyses of data from 51 epidemiological studies of 52,705 women with breast cancer and 108,411 women without breast cancer. Lancet 1997, 350, 1047-1059. [CrossRef]

37. Chlebowski, R.T.; Rohan, T.E.; Manson, J.E.; Aragaki, A.K.; Kaunitz, A.; Stefanick, M.L.; Simon, M.S.; Johnson, K.C.; Wactawski-Wende, J.; O'Sullivan, M.J.; et al. Breast cancer after use of estrogen plus progestin and estrogen alone: Analyses of data from 2 women's health initiative randomized clinical trials. JAMA Oncol. 2015, 1, 296-305. [CrossRef] [PubMed] 
38. Anderson, G.L.; Chlebowski, R.T.; Rossouw, J.E.; Rodabough, R.J.; McTiernan, A.; Margolis, K.L.; Aggerwal, A.; David Curb, J.; Hendrix, S.L.; Allan Hubbell, F.; et al. Prior hormone therapy and breast cancer risk in the Women's Health Initiative randomized trial of estrogen and progestin. Maturitas 2006, 55, 107-115. [CrossRef] [PubMed]

39. Anderson, G.L.; Chlebowski, R.T.; Aragaki, A.K.; Kuller, L.H.; Manson, J.E.; Gass, M.; Bluhm, E.; Connelly, S.; Hubbell, F.A.; Lane, D.; et al. Conjugated equine oestrogen and breast cancer incidence and mortality in postmenopausal women with hysterectomy: Extended follow-up of the Women's Health Initiative randomised placebo-controlled trial. Lancet Oncol. 2012, 13, 476-486. [CrossRef]

40. Santen, R.J.; Yue, W.; Heitjan, D.F. Modeling of the growth kinetics of occult breast tumors: Role in interpretation of studies of prevention and menopausal hormone therapy. Cancer Epidemiol. Biomark. Prev. 2012, 21, 1038-1048. [CrossRef] [PubMed]

41. Clarke, C.A.; Glaser, S.L.; Uratsu, C.S.; Selby, J.V.; Kushi, L.H.; Herrinton, L.J. Recent declines in hormone therapy utilization and breast cancer incidence: Clinical and population-based evidence. J. Clin. Oncol. 2006, 24, e49-e50. [CrossRef] [PubMed]

42. Robbins, A.S.; Clarke, C.A. Regional changes in hormone therapy use and breast cancer incidence in California from 2001 to 2004. J. Clin. Oncol. 2007, 25, 3437-3439. [CrossRef] [PubMed]

43. Zbuk, K.; Anand, S. Declining incidence of breast cancer after decreased use of hormone-replacement therapy: Magnitude and time lags in different countries. J. Epidemiol. Community Health 2012, 66, 1-7. [CrossRef] [PubMed]

44. Katalinic, A.; Lemmer, A.; Zawinell, A.; Rawal, R.; Waldmann, A. Trends in hormone therapy and breast cancer incidencedresults from the German Network of Cancer Registries. Pathobiology 2009, 76, 90-97. [CrossRef] [PubMed]

45. Seradour, B.; Allemand, H.; Weill, A.; Ricordeau, P. Sustained lower rates of breast cancer incidence in France in 2007. Breast Cancer Res. Treat. 2010, 121, 799-800. [CrossRef] [PubMed]

46. Canfell, K.; Banks, E.; Moa, A.M.; Beral, V. Decrease in breast cancer incidence following a rapid fall in use of hormone replacement therapy in Australia. Med. J. Aust. 2008, 188, 641-644. [PubMed]

47. De, P.; Neutel, C.I.; Olivotto, I.; Morrison, H. Breast cancer incidence and hormone replacement therapy in Canada. J. Natl. Cancer Inst. 2010, 102, 1489-1495. [CrossRef] [PubMed]

48. Parkin, D.M. Is the recent fall in incidence of post-menopausal breast cancer in UK related to changes in use of hormone replacement therapy? Eur. J. Cancer 2009, 45, 1649-1653. [CrossRef]

49. A Decline in Breast-Cancer Incidence. multiple letters. N. Engl. J. Med. 2007, 357, 509-513.

50. Breen, N.; Cronin, K.; Meissner, H.I.; Taplin, S.H.; Tangka, F.K.; Tiro, J.A.; McNeel, T.S. Reported drop in mammography: Is this cause for concern? Cancer 2007, 109, 2405-2409. [CrossRef]

51. Martin, R.M.; Wheeler, B.W.; Metcalfe, C.; Gunnell, D. What was the immediate impact on population health of the recent fall in hormone replacement therapy prescribing in England? Ecological study. J. Public Health (Oxf.) 2010, 32, 555-564. [CrossRef]

52. Hulley, S.B.; Grady, D. The WHI estrogen-alone trial-do things look any better? JAMA 2004, 291, $1769-1771$. [CrossRef]

53. Beral, V.; Bull, D.; Reeves, G.; Million Women Study Collaborators. Endometrial cancer and hormone-replacement therapy in the Million Women Study. Lancet 2005, 365, 1543-1551. [CrossRef]

54. Sjögrena, L.L.; Mørchb, L.S.; Løkkegaarda, E. Hormone replacement therapy and the risk of endometrial cancer: A systematic review. Maturitas 2016, 91, 25-35. [CrossRef] [PubMed]

55. Mørch, L.S.; Kjaer, S.K.; Keiding, N.; Løkkegaard, E.; Lidegaard, Ø. The influence of hormone therapies on type I and II endometrial cancer: A nationwide cohort study. Int. J. Cancer 2016, 138, 1506-1515. [CrossRef] [PubMed]

56. Jaakkola, S.; Lyytinen, H.K.; Dyba, T.; Ylikorkala, O.; Pukkala, E. Endometrial cancer associated with various forms of postmenopausal hormone therapy: A case control study. Int. J. Cancer 2011, 128, 1644-1651. [CrossRef] [PubMed]

57. Stute, P.; Neulen, J.; Wildt, L. The impact of micronized progesterone on the endometrium: A systematic review. Climacteric 2016, 19, 316-328. [CrossRef] [PubMed]

58. Fournier, A.; Berrino, F.; Clavel-Chapelon, F. Unequal risks for breast cancer associated with different hormone replacement therapies: Results from the E3N cohort study. Breast Cancer Res. Treat. 2008, 107, 103-111. [CrossRef] [PubMed] 
59. Fournier, A.; Dossus, L.; Mesrine, S.; Vilier, A.; Boutron-Ruault, M.C.; Clavel-Chapelon, F.; Chabbert-Buffet, N. Risks of endometrial cancer associated with different hormone replacement therapies in the E3N cohort, 1992-2008. Am. J. Epidemiol. 2014, 180, 508-517. [CrossRef] [PubMed]

60. Wachtel, M.S.; Yang, S.; Dissanaike, S.; Margenthaler, J.A. Hormone Replacement Therapy, likely neither Angel nor Demon. PLoS ONE 2015, 10, e0138556. [CrossRef] [PubMed]

61. Thurston, R.C.; Kuller, L.H.; Edmundowicz, D.; Matthews, K.A. History of hot flashes and aortic calcification among Postmenopausal women. Menopause 2010, 17, 256-261. [CrossRef] [PubMed]

62. Thurston, R.C.; Sutton-Tyrrell, K.; Everson-Rose, S.A.; Hess, R.; Powell, L.H.; Matthews, K.A. Hot flashes and carotid intima media thickness among midlife women. Menopause 2011, 18, 352-358. [CrossRef]

63. Bechlioulis, A.; Kalantaridou, S.N.; Naka, K.K.; Chatzikyriakidou, A.; Calis, K.A.; Makrigiannakis, A.; Papanikolaou, O.; Kaponis, A.; Katsouras, C.; Georgiou, I.; et al. Endothelial function, but not carotid intima-media thickness, is affected early in menopause and is associated with severity of hot flushes. J. Clin. Endocrinol. Metab. 2010, 95, 1199-11206. [CrossRef]

64. Writing Group for the PEPI Trial. Effects of estrogen or estrogen/progestin regimens on heart disease risk factors in postmenopausal women. The Postmenopausal Estrogen/Progestin Interventions (PEPI) Trial. JAMA 1995, 273, 199-208. [CrossRef]

65. Herrington, D.M.; Werbel, B.L.; Riley, W.A.; Pusser, B.E.; Morgan, T.M. Individual and combined effects of estrogen/progestin therapy and lovastatin on lipids and flow-mediated vasodilation in postmenopausal women with coronary artery disease. J. Am. Coll. Cardiol. 1999, 33, 2030-2037. [CrossRef]

66. Futterman, L.G.; Lemberg, L. Lp(a) lipoprotein-An independent risk factor for coronary heart disease after menopause. Am. J. Crit. Care 2001, 10, 63-67. [PubMed]

67. Störk, S.; von Schacky, C.; Angerer, P. The effect of 17-estradiol on endothelial and inflammatory markers in postmenopausal women: A randomized, controlled trial. Atherosclerosis 2002, 165, 301-307. [CrossRef]

68. Guzic-Salobir, B.; Keber, I.; Seljeflot, I.; Arnesen, H.; Vrabic, L. Combined hormone replacement therapy improves endothelial function in healthy postmeno pausal women. J. Intern. Med. 2001, 250, 508-515. [CrossRef] [PubMed]

69. Wakatsuki, A.; Okatani, Y.; Ikenoue, N.; Fukaya, T. Effect of medroxyprogesterone acetate on endothelium-dependent vasodilation in postmenopausal women receiving estrogen. Circulation 2001, 104, 1773-1778. [CrossRef] [PubMed]

70. Hodis, H.N.; Mack, W.J.; Henderson, V.W.; Shoupe, D.; Budoff, M.J.; Hwang-Levine, J.; Li, Y.; Feng, M.; Dustin, L.; Kono, N.; et al. Vascular effects of early versus late postmenopausal treatment with estradiol. N. Engl. J. Med. 2016, 374, 1221-1231. [CrossRef]

71. Harman, S.M.; Black, D.M.; Naftolin, F.; Brinton, E.A.; Budoff, M.J.; Cedars, M.I.; Hopkins, P.N.; Lobo, R.A.; Manson, J.E.; Merriam, G.R.; et al. Arterial imaging outcomes and cardiovascular risk factors in recently menopausal women: A randomized trial. Ann. Intern. Med. 2014, 161, 249-260. [CrossRef]

72. Mikkola, T.S.; Tuomikoski, P.; Lyytinen, H. Increased cardiovascular mortality risk in women discontinuing postmenopausal hormone therapy. J. Clin. Endocrinol. Metab. 2015, 100, 4588-4594. [CrossRef]

73. Kindig, D.A.; Cheng, E.R. Even as mortality fell in most US counties, female mortality nonetheless rose in 42.8 percent of counties from 1992 to 2006. Health Aff. (Millwood) 2013, 32, 451-458. [CrossRef]

74. Shetty, K.D.; Vogt, W.B.; Bhattacharya, J. Hormone replacement therapy and cardiovascular health in the United States. Med. Care 2009, 47, 600-606. [CrossRef]

75. Ilesanmi-Oyelere, B.L.; Schollum, L.; Kuhn-Sherlock, B.; McConnell, M.; Mros, S.; Coad, J.; Roy, N.C.; Kruger, M.C. Inflammatory markers and bone health in postmenopausal women: A cross-sectional overview. Immun. Ageing 2019, 16, 15. [CrossRef] [PubMed]

76. Ginaldi, L.; De Martinis, M.; Saitta, S.; Sirufo, M.M.; Mannucci, C.; Casciaro, M.; Ciccarelli, F.; Gangemi, S. Interleukin-33 serum levels in postmenopausal women with osteoporosis. Sci. Rep. 2019, 9, 3786. [CrossRef] [PubMed]

77. Banks, E.; Beral, V.; Reeves, G.; Balkwill, A.; Barnes, I. Fracture incidence in relation to the pattern of use of hormone therapy in postmenopausal women. JAMA 2004, 291, 2212-2220. [CrossRef] [PubMed]

78. Grodstein, F.; Stampfer, M.J.; Falkeborn, M.; Naessen, T.; Persson, I. Post-menopausal hormone therapy and risk of cardiovascular disease and hip fracture in a cohort of Swedish women. Epidemiology 1999, 10, 476-480. [CrossRef] [PubMed] 
79. Mosekilde, L.; Beck-Nielsen, H.; Sørensen, O.H.; Nielsen, S.P.; Charles, P.; Vestergaard, P.; Hermann, A.P.; Gram, J.; Hansen, T.B.; Abrahamsen, B.; et al. Hormonal replacement therapy reduces forearm fracture incidence in recent postmenopausal women. Results of the Danish Osteoporosis Prevention Study. Maturitas 2000, 36, 181-193. [CrossRef]

80. Watts, N.B.; Cauley, J.A.; Jackson, R.D.; LaCroix, A.Z.; Lewis, C.E.; Manson, J.E.; Neuner, J.M.; Phillips, L.S.; Stefanick, M.L.; Wactawski-Wende, J.; et al. Women's Health Initiative Investigators. No Increase in Fractures After Stopping Hormone Therapy: Results From the Women's Health Initiative. J. Clin. Endocrinol. Metab. 2017, 102, 302-308. [CrossRef]

81. Saarelainen, J.; Hassi, S.; Honkanen, R.; Koivumaa-Honkanen, H.; Sirola, J.; Kröger, H.; Komulainen, M.H.; Tuppurainen, M. Bone loss and wrist fractures after withdrawal of hormone therapy: The 15-year follow-up of the OSTPRE cohort. Maturitas 2016, 85, 49-55. [CrossRef]

82. Islam, S.; Liu, Q.; Chines, A.; Helzner, E. Trend in incidence of osteoporosis-related fractures among 40- to 69-year-old women: Analysis of a large insurance claims database, 2000-2005. Menopause 2009, 16, 77-83. [CrossRef]

83. Gambacciani, M.; Ciaponi, M.; Genazzani, A.R. The HRT misuse and osteoporosis epidemic: A possible future scenario. Climacteric 2007, 10, 273-275. [CrossRef]

84. Karim, R.; Dell, R.M.; Greene, D.F.; Mack, W.J.; Gallagher, J.C.; Hodis, H.N. Hip fracture in postmenopausal women after cessation of hormone therapy: Results from a prospective study in a large health management organization. Menopause 2011, 18, 1172-1177. [CrossRef] [PubMed]

(C) 2019 by the authors. Licensee MDPI, Basel, Switzerland. This article is an open access article distributed under the terms and conditions of the Creative Commons Attribution (CC BY) license (http://creativecommons.org/licenses/by/4.0/). 